\title{
The Size of Local Government Administration at a Municipal Level as a Determinant of Entrepreneurship
}

\section{Rusłan Harasym ${ }^{1}$, Jacek Rodzinka and Tomasz Skica ${ }^{3}$}

\begin{abstract}
This article's aim is to examine a dependency between local government administration at a municipal level and the level of local entrepreneurship. This paper attempts to answer the question of whether the size of the local government administration has features of stimulant or de-stimulant in the process of setting up a business. In other words, does the size of public administration at a local level (municipal level) have a positive or negative impact on creating new business entities? This is important due to at least a couple of reasons. First of all, the current research achievements are not extensive, when it comes to the publications that link entrepreneurship and the size of local government administration. Secondly, the problem of entrepreneurship determinants constitutes still topical and not fully investigated (or explained) aspects of local economy development. Thirdly and finally, the authors of this article have proposed and copyrighted an approach to the quantification of the size of local government administration, modifying commonly used measures of local public administration. Thus, this article fits not only into the explanation of the entrepreneurship phenomenon and its determinants, but also contributes to the development of knowledge about dependencies between the size of local selfgovernment and the entrepreneurship level. It expands the knowledge resource on analyzed dependencies and re-orients current approaches to similar research.
\end{abstract}

Keywords: territorial self-government; local public administration; self-government administration; size of local self-government; entrepreneurship; new business entities.

\footnotetext{
1 Rusłan Harasym, M.A., Department of Economics, University of Information Technology and Management, ul. Sucharskiego 2, 35-225 Rzeszow, Poland, e-mail: rharasym@wsiz.rzeszow.pl.

2 Jacek Rodzinka, Ph.D., Department of Finance, Instiute for Financial Research and Analyses, University of Informatin Technology and Management, ul. Sucharskiego 2, 35-225 Rzeszow, Poland, e-mail: e-mail: jrodzinka@wsiz.rzeszow.pl. 3 Tomasz Skica, Ph.D., Department of Finance, Institute for Financial Research and Analyses, University of Information Technology and Management, ul. Sucharskiego 2, 35-225 Rzeszow, Poland, e-mail: tskica@wsiz.rzeszow.pl.
} 


\section{INTRODUCTION}

The problem of entrepreneurship, and its stimulants and de-stimulants, is an object of continuous research. The variety of observed approaches to design research of the related factors, in which different authors seek the impact on entrepreneurship, seems to drain this research area, as an object of empirical analysis. Nevertheless this statement is precipitate and a conclusion formulated in this way is overstated. Despite the extensive research that is dedicated to entrepreneurship, this problem is still not fully covered and explained. As a result, it still remains topical and attractive from the point of view of the design of the research that is aimed to both identify and describe factors that determine (in both a positive and negative sense) the entrepreneurship level.

Of particular significance in explaining the phenomenon of entrepreneurship is the role played in this process by public administration. Knowledge about the transfer of a public authority's activity, as well as it scope and character, for the processes of initiating and setting up a business activity, is not only common, but also multi-dimensional. The following authors raised this issue in their articles: Vesper (1983), El-Namaki (1988), Westhead (1990), and Goodman, Meany and Pate (1992) indicated the following areas of stimulation of entrepreneurship by the government (public administration) and the following accompanied channels of support: provision of venture capital funds, tax-based incentives, as well as government procurement programs and protection of proprietary ideas and innovations. These authors refer also to the following areas of authorities' activity on entrepreneurship support: government agencies' support, fostering of entrepreneurship by educational institutions, as well as the minimization of barriers to entry. Gnyawali and Fogel (1994) distributed the accents in a different way and analyzing environmental conditions of entrepreneurial activities, grouped them into five dimensions, including: financial assistance, non-financial assistance, entrepreneurial and business skills, and socio-economic conditions; they also considered government policies and procedures, which stressed the role of public authorities in the process of stimulating economic initiatives.

Research, taking into account the activity of public authorities in their efforts to support entrepreneurship, has also been done in the areas beyond the above-mentioned forms and channels of support. An example that can be used is the research of Smallbone and Welter (2001), who analyzed the impact of activity of central level public administration on the development of small-to-medium enterprises (SMEs). The authors mentioned the following tools and forms of impact of entrepreneurship that are available for public 
authorities: impact on stability of the macroeconomic business environment, properly directed legislation activity, programs of entrepreneurship support, formation of an institutional environment for companies, as well as the formation of entrepreneurial behaviors in society by, inter alia, the educational system. Minniti (2008) considers the role of government policy in formulating the institutional environment for companies and concentrates on identification of these public authorities' policies, which affect entrepreneurship support in the most productive (effective) way. Shane (2009) concentrates his considerations on start-ups and proves that the involvement of public authorities in support of such initiatives should not have an "automatic" nature. Due to the fact that not every start-up translates into economic growth and job creation, the approach of authorities to support economic activities should have a selective nature and an orientation towards ventures and pro-growth companies. Valdez and Richardson (2013) analyze institutional determinants of macro-level entrepreneurship and prove that regulative institutions are related to entrepreneurial activity. Whereas Fuentelsaz, González, Maícas and Montero (2015), studying the impact of formal institutions on entrepreneurship, evaluate elements of the entrepreneurship environment by referencing the classification of Gnyawali and Fogel (1994) that covers property rights, business freedom, fiscal freedom, labor freedom, financial capital and educational capital. According to the authors' opinion, the goal of public authorities' policy aimed at supporting entrepreneurship, should be to ensure the efficiency of market mechanisms by eliminating market failures and administrative restrictions for setting up and developing a business.

Despite the fact that the presented calculation is not exhaustive and present in the literature to explain the dependency linking the activity of public authorities (administration) with entrepreneurship, it draws attention to some important regularity. Firstly, approaches adopted in the literature attempting to explain the entrepreneurship phenomenon are made through the prism of authorities' activities and relate mainly to the activity of public administration at the central level, as well as its role in the process of creating the institutional and regulatory environment in the area of initiating and running a business. Secondly, even if what is present in the literature attempts to refer to the level of activity of local government, the subject of analysis and related arrangements are most commonly those instruments of entrepreneurship support and/or the effects of actions of local authorities that support entrepreneurship, not the relation between the size of local government (as stimulants or de-stimulants) with the level of entrepreneurship. The following authors proved these observations: Bania and Dahlke (2014), Dyrda (2014), Dropek (2014), as well as Grycuk and Russel 
(2014), Korolewska (2014), or Rapacz and Jareman (2014). These articles classify and group instruments of entrepreneurship support that are available for local government administration, and assess their effectiveness and usefulness in the activities of public authorities that are aimed at stimulating the development of the local economy. At the same time these articles stress that, apart from the identification of the effectiveness of these forms of support, much depends on the size of local government administration.

Today, there is no doubt about the fact that there is a negative impact from the excessive growth of regulations, and consequent readjustment of the economy to entrepreneurship (cf., inter alia, Klapper, Laeven and Rajan, 2006; Van Stel, Storey \& Thurik, 2007; Parker, 2007; Djankov, La Porta,

Lopez-de-Silanes and Shleifer, 2002). The same situation can be observed in the case of better conditions of entrepreneurship with proper (i.e. adjusted to real needs of businesses) support from the government side (in a regulative, institutive and fiscal sense). A pointless discussion can also be observed in the case of equipping self-government authorities by legislation, understood as tools that self-governments use in order to create conditions for setting up new businesses and stimulating their growth (cf., inter alia, Walenia 2014, Skica \& Bem, 2014). Finally, there is a commonly known position in accordance to which an introduction of solutions aimed at entrepreneurship stimulation by the existing legal order, as well as making them available for creators of the local socio-economic reality (local governments), is not identical to their effective use (cf., inter, alia Motoyama \& Viens, 2015). Even the exemplary solutions introduced to support economic activity do not always correspond to a level of entrepreneurship development that is adequate when compared to the scale of the applied forms of support. In both presented situations, their background has separate justification. As in the first case, the causative factor might be badly executed local government policy on entrepreneurship support (Skica, Bem \& Daszyńska-Żygadło, 2013), insofar as in the second situation this factor might be a low level of social capital (Westlund \& Bolton, 2003) which, even in the assumption of properly constructed frameworks of support, will result in only partitive outcomes in the form of entrepreneurship development.

As indicated in the conducted analysis, the background of problems in the relationships between public administration (and the related activity focused on economic entities) and entrepreneurship, can have at least three centers. The first of them may be the wrong policies of public authorities (on both a central and local level) in actions taken to support entrepreneurship. A policy carried out in the wrong way might be conditioned by the misunderstanding of the actual needs of entrepreneurs, their wrong diagnoses, improper choice of support instruments and finally ignoring the signals coming from 
the environment and indicating the real expectations of forms of support. The second background was independent (exogenous) factors in relation to the activity of public administration. In this group, the authors included inter alia low social potential, passivity of the community on the offered forms of support, as well as institutional barriers and inadequate socio-economic infrastructure. Finally, the third component of the base of the problems associated with the development of entrepreneurship is the lack of dialogue between public authorities and entrepreneurs. These indicated problems complement the previously presented diagnosis. No dialogue corresponds with the ignorance of the local environment needs, and thus the improper creation of supporting policies. At the same time, the lack of opportunity to get recipients of these actions to express themselves on the above topic results in a shortage of feedback in the direction of the authorities on the consequences of the actions taken by them (cf., Smallbone, 2007, p. 203). This situation causes a bilateral defect of relations between the regulator and the receiver of regulation, which in turn translates into a lack of a linear dependency between the activity of public authorities on applied support and the level of entrepreneurship.

The presented findings proved a basic regularity. The approaches occurring in the literature to research on the relation of public administrationentrepreneurship concentrates on the effects of actions of the public authorities (on a central and local level) on the processes of entrepreneurship stimulation. The attempts at analyzing entrepreneurship in the contexts of public authorities' presents the aspect of public administration size as a stimulant or de-stimulant of entrepreneurship to a relatively small extent (cf., inter alia, Aidis, Estrin \& Mickiewicz, 2012; Casero, Aunión, Escobedo \& Mogollón, 2015). Considering the above, the purpose of this article is to examine the impact of the size of public administration in Poland on the level of entrepreneurship. Due to the fact that the creator of entrepreneurship development is the local government that uses the attributes of its authority and implements the established rules into economic practice, this article is devoted to a review of relations along the lines of: size of local government at the local level (municipal) in Poland - level of entrepreneurship.

The section "Introduction" justifies the designing process of scientific research that was dedicated to explain the phenomenon of entrepreneurship from the perspective of its relations with the size of the local government administration. In the section "Literature review" the authors will present the analysis of the historically applied approaches to quantify the size of local government administration. It is essential for the next phase of scientific research that is set as modeling the relations between the size of public administration and entrepreneurship. In the section "Data, methods and 
model specification", the authors presented variables that were applied in the research and these were selected in accordance with the "Literature review" section's analysis of historical research that used size of local government administration as an independent variable. In the next step, the authors will discuss the applied research method. This section finishes with a modeling of interdependency that is presented in the article's title. Finally, the section "Results" brings obtained results closer, whereas their description is presented in the section "Discussion and Conclusions".

\section{LITERATURE REVIEW}

The argument that was presented in the previous part of this article justifies launching the analyses to review current literature approaches to measure the size of the public administration on a local level. Such a solution on the one hand enables a diagnosis of currently used measurements and on the other hand will open up opportunities for proposing alternative solutions to measure the size of the local government administration. It should be stressed that the approach presented below provides an overview of the current literature on measures of administrative structures dedicated to various aspects of activity of the public sector as well as its economic functions. This solution offers the possibility of selecting measures of size of public government beyond the standard attempts to link the activity of public authorities and entrepreneurship.

\section{Quantification of local administration size}

The literature review proves decidedly that the most frequent measures of public administration size in total (including local government administration) are: level of spending and number of employees. This position is proved in the following publications: Heller and Tait (1983), Weiher and Lorrence (1991), as well as Mackenzie (1991), use the ratio of employment in self-government units as a measure of local administration size. On the other hand Hemming (1991) and Kalseth and Rattso (1995) describe the size of local administration using the level of its total spending. Baqir (1999) describes the size of public administration structures using two measures. The first is the comparison of total expenses and total income of the entity, while the second is the number of employees in local government per capita of the local government unit under investigation.

A different point of view on the measurement of the size of public administration on a local government level was expressed in the article of 
Ivanov, Tchavdarova, Savov and Stanev (2002). The authors present the size of the local public administration using three methods. The first approach is a separation of the total expenditure of resources used for maintenance of the unit. The second method is based on relating the expenditure on administration to the total expenditure of local government. The third method divides expenditure on administrative matters by the number of residents of the examined territorial unit. Using these approaches, the authors obtained a measure of the costs of territorial administration functioning. Sellers, Barnes, Hoffmann-Martinot and Shipper (2003) as well as Higgins, Young and Levy (2006), apart from financial measures, indicate employment as the measure of size of the local government administration. The mentioned exponent of size of the local government administration is considered from the point of view of both the number of people employed in the local government unit and in relation to total employment in the public administration (on the central and local government unit) of a given country.

Explanation of size of the local government administration by the expenditure measures is also used by Garrett and Rhine (2006). They carry out the measurement of administration (on both central and local government level) using its spending per capita, and at the same time they verify the factors responsible for their level and the change (their increase or decrease). Simultaneously, as a measure of the administration size, the authors indicate the share of employment in its structures in relation to the total employment in the territorial unit (local, supra-local, etc.). Phillips and Chen (2007) take a different approach to measure the size of the local government administration. They propose the share of expenditure of local government into total public spending (government and self-government) on consumption, as well as the share of spending on local government administration in the total expenditure of a territorial unit. The authors extend the traditionally used spending measures by the analysis of the local government income in relation to public expenditure on consumption. Dollery and Robotti (2008) and in analogy to Ivanov et al. (2002) use the ratio called cost of public service provision on the examined territorial unit. This ratio is calculated as the amount of expenditure made by the self-government on public services per capita. In addition to the measures indicated above the authors, in order to specify the size of local government, use the ratio of the number of employees in local government to the area (territorial dimension), occupied by the administrative unit.

In the article of Labonte (2010), we can find a kind of synergy of the main measures of a public administration size, which were mentioned above. The author, in order to determine its size, uses both the total amount of expenditure incurred by public administration (on respectively a central or 
local level), the amount of expenditure per capita, as well as employment in its structures. However, in contrast to the above-mentioned articles, M. Labonte extends the methodology for measuring the size of government administration and local government administration by the value of generated revenues (but not income) of budget. Modification of the previously discussed measures can be also found in the articles of Boex (2011) and Boex (2012). The author, besides the measurement of a public administration structures' size through incurred expenses, proposes for this purpose to apply the degree of expenditure decentralization, defined as the value of the funds spent by individual governments on their own tasks (excluding spending on tasks assigned by the central government). At the same time J. Boex, similarly to M. Labonte, emphasizes the desirability of expressing the size of local government administration through budget revenues. The author proposes to use for this purpose the revenue side of the budget. In his opinion, the postulated measure finds justification in the lack of adequacy between the cost of realization of the public tasks that are allocated to local governments and the efficiency of sources of income that are allocated to them.

The review of approaches to measure the size of the public administration structures presented above is not exhaustive. Pevcin (2012), in research on the size of administration, refers to the total expenditure per capita incurred by self-governments at the local level for the realization of tasks that are allocated to them. Anderson (2011), indicates employment in particular units of territorial division as a measure of local government structures. A similar position is found in the articles of Bardes, Shelley and Schmidt (2014), as well as Garand, Ulrich and Xu (2013). On the other hand Salvino (2007) describes the size of local government through the prism of the two other variables. The first is self-government tax incomes referred to as personal income, while the second is the share of individual incomes of self-governments in personal incomes. Aidis, Estrin and Mickiewicz (2010) expressing the size of public administration on a national level, used the category size of the government sector (government spending) in the economy contributed by the Heritage Foundation, as well as the ratio of government expenses to GDP, i.e. the ratio proposed by the World Bank. Finally, Casero et al. (2015), measured the size of the government (public administration) using the variable size of government extracted from the Economic Freedom of the World (EFW) and the Index of Economic Freedom (IEF) published by the Heritage Foundation.

This classification, despite the diversity of approaches to measure the size of the structures of public administration (at central and local level), does not exhaust the possibilities of their quantification. As a result, and despite the plurality of the presented approaches, the review that was made by the 
authors maintains a place to propose alternative measures and approaches that are aimed at expressing the size of a public administration.

\section{Size of public administration vs. entrepreneurship}

Analysis of the literature indicated leading approaches to the attempts to quantify the size of public administration structures on both central and local levels. It clearly demonstrated that research on the measurement of the size of the administrative structures is strongly turned towards the central level. Analogically, a review of research dedicated to relationships between the size of the public authorities (government) and entrepreneurial activity, proved that attempts to explain this phenomenon are not made at the local level. Combining entrepreneurial activity with the size of public authorities (administration), along with a variety of approaches to its expression, focuses on public administration of the whole country, possibly on the administration of the central level (government level), without referring to the level of local authorities.

Nyström (2008), proves that the smaller the government sector, the greater the entrepreneurship. Bjornskov and Foss (2008) prove that a bigger public sector tends to decrease entrepreneurship. On the other hand, Aidis, Estrin and Mickiewicz (2010), state that there is a significant and robust negative relationship between the size of the state sector and entrepreneurship. Results of the research of Casero et al. (2015) provide empirical proof of an inverse relationship between the size of government and entrepreneurship, but only for efficiency-driven economies and innovation-driven economies.

In turn, the results from other research indicate that in order to assess the relationships between the level of entrepreneurial activity and the size of the public administration (government size), the level of economic development of the country is important. What is vital and regardless of the level of economic development of the country, there is no doubt that the smaller size of the public administration (government) has a positive effect on entrepreneurship, but many different levels of economic development correspond with other factors that justify smaller size of public administration structures to stimulate entrepreneurship.

According to Heckelman (2000), in the situation of underdeveloped countries, the small size of the public administration (government) stimulates entrepreneurship, due to the lack of solutions that cover society from the social side through transfers, subsidies and other forms of support. Larroulet and Kouyoumdjian (2009) show that in developing countries a small government sector (small size of the public administration) promotes the 
emergence of new entrepreneurs. The causative factor here is opportunitybased entrepreneurship. On the other hand, in highly developed countries a smaller size of the public administration (government), determines the entrepreneurship due to a smaller range of regulations related to setting up new businesses (a higher level of economic freedom). In these countries, the market is not exceedingly protected by the state, and the economy is dominated by state-owned companies and public investment (Acs and Szerb, 2007). At this point it should be noted that in the case of highly developed countries, it is easy to observe the so-called "welfare trap". As was proved by Henrekson (2005), a strong welfare state can reduce the incentives for necessity entrepreneurs. A similar position was expressed also by Koellinger and Minniti (2009).

If we move the results of analyses on the examined dependency on the level of the most commonly used measures that express the size of the public administration (government size), based on differently configured public spending, we get a much broader spectrum of information about the relationships between the analyzed variable and entrepreneurship. It should be stressed that the results of research combine and compare the level of entrepreneurship with the size of the public administration (public authorities) on a central level, not a local one. If we take the level of the realized spending as a measure of the size of the administrative structure, we will note that according to Holder (2009) higher spending translates into weaker constraints of budgetary spending and may cause reorientation of expenditure policy motives from social security to political purposes, thereby inhibiting entrepreneurship. Moreover and Parker (2004) states that a large state sector, due to its fiscal policy may even stop entrepreneurship development. Relatively high social spending eliminates the need for taking any initiatives aimed at raising revenues, by subsidizing them effectively. Nica (2014), states that entrepreneurship is negatively correlated with shares of general government final consumption expenditure and government expense out of GDP. On the other hand Islam (2015) stresses a negative relationship between total government consumption expenditure and entrepreneurial activity.

The conducted analysis confirms the research findings made so far. The ongoing study does not take into account the problems of impact of the size of administration (size of government) on local level to the level of entrepreneurship. At the same time attempts to quantify the size of the public administration structures are made predominantly in relation to public administration of an entire country, or eventually to the central administration 
(i.e. the government administration). The main exponent of the size of their structures is thereby public spending, which is configured in various ways. Measures of administration structures, which are based on the number of employed public officials, are not matched with entrepreneurial activity.

\section{DATA, METHODS AND MODEL SPECIFICATION}

The authors used for the analysis data from the sources of Local Data Bank (LDB) provided by Central Statistical Office of Poland (GUS). The geographical range of the analysis covered 2481 communes in Poland.

During the preparation of data for analysis, the authors took the output dependent variable (the number of newly registered enterprises) and divided it by the population of working age. The output independent variables were in turn divided by the total population. A further analysis was carried out on the basis of logarithmic annual data collected at the level of individual communes (2003-2013) that was later on arranged in the panel.

In the model presenting the impact of expenditure on salaries of civil servants on entrepreneurship, the authors used the following variables:

1) A dependent variable that describes the level of entrepreneurship in the area of examined communes:

- Innowo_zarejes - number of newly registered businesses;

2) Independent variables:

- Inl_stud - number of higher education students/total population (log);

- Inpodm_og - number of business entities/total population (log);

- Inludnosc_poprod - population at post-working age/total population (log);

- Inludnosc_pprod - population at pre-working age/total population (log);

- Inwyd_wyn_urze - expenditure on salaries of public officers/total population (log);

- Inwyd_gmin_adm - expenditure of communes on administration/total population (log);

- Inwyd_poz_plac-non-wage expenditure of communes/total population (log).

Table 1 shows descriptive statistics of variables included in the model.

The data analysis conducted by using a correlation coefficient showed the strong relations that occurred between particular variables. The strongest interrelation with the dependent variable had the following ratios: number of 
business entities/total population (0.7928), population at post working age/ total population (0.3607) and number of higher education students/total population (-0.3247), but in the last case the correlation was negative.

Table 1. Descriptive statistics

\begin{tabular}{llllll}
\hline Variables & Obs & Mean & Std. Dev. & Min. & Max. \\
\hline 1. Innowo_zarejes & 12.394 & -4.611423 & 0.4060614 & -6.784457 & -0.2068736 \\
2. Inl_stud & 24.622 & -0.3384069 & 1.5155655 & -7.184738 & 3.418671 \\
3. Inpodm_og & 27.248 & -2.727968 & 0.3844043 & -3.869826 & -0.2732933 \\
4. Inludnosc_poprod & 27.248 & 7.226309 & 0.8093044 & 5.123964 & 12.86515 \\
5. Inludnosc_pprod & 27.204 & -1.602767 & 0.4690802 & -2.591457 & -0.3192866 \\
6. Inwyd_wyn_urze & 14.866 & 5.220366 & 0.2998009 & 4.239679 & 7.276773 \\
7. Inwyd_gmin_adm & 19.817 & 5.669386 & 0.3623588 & 2.915838 & 8.186209 \\
8. Inwyd_poz_plac & 14.732 & 4.823158 & 0.4183566 & -0.0549102 & 8.105982 \\
\hline
\end{tabular}

Presented below, Table 2 shows correlation coefficients of variables included in the model.

Table 2. Correlation matrix

\begin{tabular}{|c|c|c|c|c|c|c|c|c|}
\hline & 1. & 2. & 3. & 4. & 5. & 6. & 7. & 8. \\
\hline 1. Innowo_zarejes & 1.0000 & & & & & & & \\
\hline 2. Inl_stud & -0.3247 & 1.0000 & & & & & & \\
\hline 3. Inpodm_og & 0.7928 & -0.4064 & 1.0000 & & & & & \\
\hline 4. Inludnosc_poprod & 0.3607 & -0.4517 & 0.4595 & 1.0000 & & & & \\
\hline 5. Inludnosc_pprod & -0.0080 & 0.1365 & -0.0936 & -0.1144 & 1.0000 & & & \\
\hline 6. Inwyd_wyn_urze & -0.1010 & 0.2218 & -0.0544 & -0.5085 & 0.0619 & 1.0000 & & \\
\hline 7. Inwyd_gmin_adm & -0.0881 & 0.1693 & -0.0118 & -0.4217 & 0.0100 & 0.8333 & 1.0000 & \\
\hline 8. Inwyd_poz_plac & -0.0226 & 0.1271 & 0.0250 & -0.3311 & 0.0036 & 0.6332 & 0.9081 & 1.0000 \\
\hline
\end{tabular}

The strongest relationship between independent variables occurred in the case of the following pairs of variables: expenditure of communes for administration/total population and the non-wage expenditure of municipalities/total population (0.9081); expenditure on salaries of public officers/total population and expenditure of municipalities for administration/total population (0.8333); expenditure on salaries of public officers/total population and the non-wage expenditure of communes/total population (0.6332); population at post-working age/total population and expenditure on salaries of public officers/total population (-0.5085); number of business entities/total population and the population at post-working age/ total population (0.4595); population at post-working age/total population and expenditure of communes on administration/total population (-0.4217); number of higher education students/total population and number of business entities/total population (-0.4064). 
In the next step, the variables were used to estimate models that have the following algebraic characteristic:

1) models calculated based on observations for types of communes (urban, rural and urban-rural):

Innowo_zarejes $=\beta 0+\beta 1$ (Inl_stud) $+\beta 2$ (Inpodm_og) $+\beta 3$ (Inludnosc poprod) $+\beta \overline{4}$ (Inludnosc_pprod) $+\beta 5$ (Inwyd_wyn_urze) $+\mu$ (Model 1)

Innowo_zarejes $=\beta 0+\beta 1$ (Inl_stud) $+\beta 2$ (Inpodm_og) $+\beta 3$ (Inludnosc_ poprod) $+\beta 4$ (Inludnosc_pprod) $+\beta 5$ (Inwyd_wyn_urze) $+\beta 6$ (Inwyd_gmin_ adm $)+\mu$........... (Model 2) Innowo_zarejes $=\beta 0+\beta 1$ (Inl_stud) $+\beta 2$ (Inpodm_ og) $+\beta 3$ (Inludnosc_poprod) $+\beta 4$ (Inludnosc_pprod) $+\beta 5$ (Inwyd_wyn_urze) $+\beta 6$ (Inwyd_poz_plac) $+\mu$

(Model 3)

2) models calculated based on observations for urban communes:

Innowo_zarejes $=\beta 0+\beta 1$ (Inl_stud) $+\beta 2$ (Inpodm_og) $+\beta 3$ (Inludnosc_ poprod $)+\beta 4$ (Inludnosc_pprod) $+\beta 5$ (Inwyd_wyn_urze) $+\beta 6$ (Inwyd_gmin $\operatorname{adm})+\mu$ (Model 2.1)

Innowo_zarejes $=\beta 0+\beta 1$ (Inl_stud) $+\beta 2($ Inpodm_og $)+\beta 3$ (Inludnosc_ poprod) $+\beta 4$ (Inludnosc_pprod) + $\beta 5$ (Inwyd_wyn_urze) + $\beta 6$ (Inwyd_poz_ plac) $+\mu$

(Model 3.1)

3) models calculated based on observations for rural communes:

Innowo_zarejes $=\beta 0+\beta 1$ (Inl_stud) $+\beta 2$ (Inpodm_og) $+\beta 3$ (Inludnosc_ poprod) $+\beta \overline{4}$ (Inludnosc_pprod) $+\beta 5$ (Inwyd_wyn_urze) $+\beta 6$ (Inwyd_gmin $\mathrm{adm})+\mu$ (Model 2.2)

Innowo_zarejes $=\beta 0+\beta 1$ (Inl_stud) $+\beta 2$ (Inpodm_og) $+\beta 3$ (Inludnosc_ poprod) $+\beta 4$ (Inludnosc_pprod) + $\beta 5$ (Inwyd_wyn_urze) $+\beta 6$ (Inwyd_poz_ plac) $+\mu$.

(Model 3.2)

4) models calculated based on observations for urban-rural communes Innowo_zarejes $=\beta 0+\beta 1$ (Inl_stud) $+\beta 2$ (Inpodm_og) $+\beta 3$ (Inludnosc_ poprod $)+\beta 4$ (Inludnosc_pprod) $+\beta 5$ (Inwyd_wyn_urze) $+\beta 6$ (Inwyd_gmin_ $\operatorname{adm})+\mu$ (Model 2.3)

Innowo_zarejes $=\beta 0+\beta 1$ (Inl_stud) $+\beta 2$ (Inpodm_og) $+\beta 3$ (Inludnosc_ poprod) $+\beta 4$ (Inludnosc_pprod) + $\beta 5$ (Inwyd_wyn_urze) + $\beta 6$ (Inwyd_poz_ plac) $+\mu$. (Model 3.3)

Estimation of parameters in panels with a fixed effect was conducted using Stata 14 software. Detailed results of regression analysis are presented in the next part of this article. 


\section{RESEARCH METHODS}

Results of parameter estimation for particular models are presented in Table 3.

Table 3. Regression results

\begin{tabular}{|c|c|c|c|c|c|c|c|c|c|}
\hline Independent & Model 1 & Model 2 & Model 2.1 & 1 Model 2.2 & 2 Model 2.3 & 3 Model 3 & Model 3.1 & 1 Model 3.2 & 2 Model 3.3 \\
\hline Inl_stud & $0.0281^{* *}$ & $0.0281^{* *}$ & $0.0531^{*}$ & $0.0319^{*}$ & 0.0012 & $0.0281^{* *}$ & $0.0534^{* *}$ & $0.0323 *$ & 0.0000 \\
\hline & $(0.0107)$ & $(0.0107)$ & $(0.0237)$ & $(0.0148)$ & $(0.0183)$ & $(0.0108)$ & $(0.0238)$ & $(0.0149)$ & $(0.0184)$ \\
\hline Inpodm_og & $2.0484^{* * *}$ & $2.0491 * * *$ & $2.1980 * * *$ & $2.0761 * * *$ & k $1.8798^{* * *}$ & $2.0466 * * *$ & $2.1933^{* * *}$ & $2.0741^{* * *}$ & $1.8731^{* * *}$ \\
\hline & $(0.0893)$ & $(0.0893)$ & $(0.3501)$ & $(0.0881)$ & (0.1292) & (0.0899) & $(0.3536)$ & $(0.0885)$ & $(0.1297)$ \\
\hline $\begin{array}{l}\text { Inludnosc_ } \\
\text { poprod }\end{array}$ & $0.2218^{* *}$ & $0.2225^{* *}$ & $0.6209 * *$ & 0.1044 & $0.3702^{*}$ & $0.2146^{* *}$ & $0.6244^{* *}$ & 0.1014 & $0.3393^{*}$ \\
\hline & $(0.0815)$ & $(0.0815)$ & $(0.2262)$ & $(0.1050)$ & $(0.1601)$ & $(0.0821)$ & $(0.2265)$ & (0.1059) & (0.1594) \\
\hline $\begin{array}{l}\text { Inludnosc_ } \\
\text { pprod }\end{array}$ & $-0.3512 * *$ & $-0.3509 * *$ & 0.0300 & $-0.4379 * *$ & -0.2297 & $-0.3521 * *$ & 0.0279 & $-0.4336^{* *}$ & -0.2524 \\
\hline & $(0.1167)$ & $(0.1168)$ & $(0.2960)$ & $(0.1465)$ & $(0.2194)$ & (0.1181) & $(0.2993)$ & (0.1478) & $(0.2183)$ \\
\hline $\begin{array}{l}\text { Inwyd_wyn_ } \\
\text { urze }\end{array}$ & $-0.0684 *$ & -0.0683 & $-0.1720 * *$ & $-0.0959 *$ & 0.0986 & $-0.0715^{*}$ & $-0.1667^{*}$ & $-0.0950 *$ & 0.0827 \\
\hline & $(0.0345)$ & $(0.0366)$ & $(0.0820)$ & $(0.0485)$ & $(0.0655)$ & $(0.0354)$ & (0.0809) & $(0.0461)$ & $(0.0652)$ \\
\hline $\begin{array}{l}\text { Inwyd_gmin_ } \\
\text { adm }\end{array}$ & & -0.0004 & 0.0186 & 0.0018 & -0.0083 & & & & \\
\hline & & $(0.0157)$ & $(0.0317)$ & $(0.0215)$ & $(0.0250)$ & & & & \\
\hline $\begin{array}{l}\text { Inwyd_poz_- } \\
\text { plac }\end{array}$ & & & & & & 0.0007 & 0.0186 & -0.0036 & 0.0098 \\
\hline & & & & & & $(0.0092)$ & $(0.0171)$ & (0.0119) & $(0.0171)$ \\
\hline Constant & -0.8725 & -0.8724 & -3.6540 & 0.2686 & -3.2629 & -0.8107 & -3.7089 & 0.3150 & -3.0959 \\
\hline N obs & 12,329 & 12,321 & 1,514 & 7,793 & 2,989 & 12,204 & 1,504 & 7,726 & 2,949 \\
\hline $\mathrm{N}$ group & 2,475 & 2,473 & 304 & 1,563 & 601 & 2,464 & 303 & 1,559 & 597 \\
\hline $\mathrm{F}$ & 229.04 & 206.15 & 54.35 & 144.38 & 67.83 & 202.28 & 54.24 & 141.67 & 67.17 \\
\hline $\mathrm{R}^{2}$ & 0.2276 & 0.2276 & 0.4800 & 0.2009 & 0.2435 & 0.2270 & 0.4797 & 0.2001 & 0.2435 \\
\hline
\end{tabular}

Robust standard errors in parentheses; *** $p<0.001 ;{ }^{* *} p<0.01 ;{ }^{*} p<0,05$.

The authors presented the above 9 models. In models 1, 2 and 3 the research adopted 2475 observations for urban, rural and rural-urban communes. This number is smaller than the total number of communes in Poland, due to the fact that the calculations were made only on these units (communes), for which all data were available for the selected variables. Models 2.1, 3.1 took into account the 304 communes, models 2.2, 3.2, in turn, took into account the 1563 rural communities, while models 2.3 and 3.3 were calculated on 601 urban-rural communes. 
For all models, the authors calculated the F-Fischer-Snedecor statistics, as its calculated value indicates the correctness of the models' specification. The determination coefficients for all models ranged from 0.2001 to 0.4800 , which indicates a relatively good fit of models.

In Model 1, the authors adopted the following independent variables: number of higher education students/total population, number of business entities/total population, population at post-working age/total population, population at pre-working age/total population, expenditure on salaries of public officers/total population. The strongest impact on the dependent variable was observed in the case of the following variables: number of business entities/total population (2.0484), population at pre-working age/total population $(-0.3512)$, as well as population at post-working age/total population (0.2218).

In order to build Model 2 the authors took the same variables as in Model 1 and added one additional variable, i.e. expenditure of communes on administration/total population. In general, it does not affect the ratios for particular variables. The strongest impact occurred in the case of the following variables: number of business entities/total population (2.0491), population at pre-working age/total population (0.3509), population at postworking age/total population (0.2225). A newly-adopted variable was found as the one with a very small negative impact on the dependent variable $(-0.0004)$.

Model 3 adopted the same explanatory variables as in Model 1 and one additional variable called non-wage expenditure of communes/total population. Also in this case, the particular ratios did not drastically change. The newly-added variable has an impact on the dependent variable to a limited extent (0.0007).

Model 2.1 was calculated only for urban communes and adopted the following explanatory variables: number of higher education students/ total population, number of business entities/total population, population at post-working age/total population, population at pre-working age/total population, expenditure on salaries of public officers/total population and expenditure of communes on administration/total population. The strongest impact on dependent variable was observed in the case of the following ratios: number of business entities/total population (2.1980), population at post-working age/total population (0.6209), expenditure on salaries of public officers/total population (0.1720). The remaining variables had low importance.

In Model 3.1, the authors adopted the same variables as in Model 2.1, with the one exemption of variable called non-wage expenditure of communes/total population, which replaced the variable called expenditure 
of communes on administration/total population. When it comes to ratios of particular variables, this replacement had not any significant importance. The variable called non-wage expenditure of communes/total population had low impact on the dependent variable (0.0186).

Model 2.2 was calculated only for rural communes and took into consideration the following explanatory variables: number of higher education students/total population, number of business entities/total population, population at post-working age/total population, population at pre-working age/total population, expenditure on salaries of public officers/ total population and expenditure of communes on administration/total population. The strongest impact on explanatory variable had the following variables: number of business entities/total population (2.0761), population at pre-working age/total population (0.4379), population at post-working age/total population (0.1044), expenditure on salaries of public officers/total population (-0.0959). The other variables had very small importance.

In Model 3.1, the authors adopted the same variables as in Model 2.1, with the one exemption of the variable called non-wage expenditure of communes/total population, which replaced the variable called expenditure of communes on administration/total population. This change had no impact on ratios of particular variables. The variable called non-wage expenditure of communes/total population had a small impact on the dependent variable $(-0.0036)$.

Model 2.2 was calculated for urban-rural communes and took into consideration the following explanatory variables: number of higher education students/total population, number of business entities/total population, population at post-working age/total population, population at pre-working age/total population, expenditure on salaries of public officers/total population and expenditure of communes on administration/ total population. The strongest impact on the dependent variable was observed in the case of the following variables: number of business entities/ total population (1.8798), population at post-working age/total population (0.3702), population at pre-working age/total population $(-0.2297)$, expenditure on salaries of public officers/total population (0.0986). The remaining variables had small importance.

In Model 3.1, the authors adopted the same variables as in Model 2.1, with the one exemption of the variable called non-wage expenditure of communes/total population, which replaced the variable called expenditure of communes on administration/total population. When it comes to ratios of particular variables, this replacement had no significant importance. The variable called non-wage expenditure of communes/total population had a small impact on the dependent variable (0.0098). 


\section{DISCUSSION AND CONCLUSION}

Analysis of correlation relationships proved that in the case of all communes the dependent variable was impacted in a positive and strong way by the following variables: number of business entities/total population (0.7928) and population at post-working age/total population (0.3607). Strong, but negative impact on the variable called number of newly registered businesses was observed in the case of the variable number of higher education students/ total population (0.3247).

Analysis of independent variables proved strong relationships between examined expenditure variables including: expenditure on salaries of public officers/total population, expenditure of communes on administration/ total population and non-wage expenditure of communes/total population. As these relationships are not a surprise, what is interesting is the negative dependency between the variable called number of higher education students/total population and number of business entities/total population and population at post-working age/total population. Results of the examined dependency suggest that the smaller the number of students residing in the commune, the larger the number of business entities.

Regression analysis allowed the authors to draw very interesting conclusions. In the case of all analyzed communes, the largest impact on the dependent variable number of newly registered businesses had the variable called number of business entities/total population. In parallel, it deserves to be mentioned that the target impact was observed in the case of urban communes (2.1980), a bit smaller in rural communes (2.0761), and the smallest in urban-rural communes (1.8798).

The independent variable called population at post-working age/ total population has the largest influence on the dependent variable in urban-rural communes (0.6209), slightly smaller in the case of urban-rural communes (0.3702), and smallest in relation to rural communes (0.1044). In turn, the variable called population at pre-working age/total population has greatest importance in rural communes $(-0.4379)$, smaller in the urbanrural communes (-0.2297), and totally marginal in urban communes $(0.0300)$. It is worth mentioning that in the case of municipalities the coefficient has a positive sign.

Finally, the variable called expenditure on salaries of public officers/total population had a strong impact on the dependent variable, when it comes to urban communes $(-0.1720)$ and only a bit weaker in urban-rural communes (0.0986) and rural communes (-0.0959). 
The conducted analysis in division on generic categories of communes revealed relatively significant differences in the influence of independent variables on the dependent variable, i.e. number of newly registered businesses/total population at working age. The variable population at pre-working age/total population has large importance in rural and urbanrural communes, whereas marginal in urban communes, where this ratio additionally occurs with a positive sign. The variable called expenditure on salaries of public officers/total population is the most significant in urban communes, has the smallest importance and additionally a positive sign in urban-rural communes, yet it has decidedly the smallest meaning in rural communes. The variable called number of higher education students/ total population is the most important in urban communes, slightly less significance in rural communes and totally marginal importance in urbanrural communes.

The main objective of this article is to answer the question of whether the size of public administration at the local level (communal level), has a positive or a negative effect on the creation of new businesses. Analysis of the literature showed that the local government is undoubtedly the creator of enterprise development because it is endowed with attributes of power and implements the established rules into economic practice. There are various types of measures adopted, as a measure of the size of the public administration in general, including the size of the local administration. In the case of this article, there are three indicators adopted as a measure of the size of the public administration: 1) expenditure on salaries of public officers/total population; 2) expenditure of communes on administration/ total population; 3) non-wage expenditure of communes/total population. The correlation analysis between adopted measures of the size of public administration did not show a strong relationship between them and the entrepreneurship that is represented in this model, as a number of newly registered businesses/total population at working age. The strongest relationship with the dependent variable was observed for the variable called expenditure on salaries of public officers/total population (-0.1010), a slightly smaller one with the variable called expenditure of communes on administration/total population (-0.0881), whereas it was marginal in the case of variable non-wage expenditure of communes/total population $(-0.0226)$. Attention has to be drawn to an important and interesting fact - the correlation between dependent variable and all three explanatory variables is meager, but in all cases occurs with a negative sign, which indicates a limited (inconsiderable) but negative impact of local administration's size on the level of entrepreneurship. 
Regression analysis allowed the authors to draw similar conclusions to those that were given in correlation analysis. The strongest impact on the entrepreneurship level is exerted by the variable called expenditure on salaries of public officers/total population. The remaining examined variables have limited importance; nevertheless the variable called non-wage expenditure of communes/total population has small positive relationships.

By varying the communes by the type, it can be determined that expenditure on salaries of public officers/total population shows the strongest impact on the dependent variable in urban communes $(-0.1720)$, similarly but with opposite signs in the case of rural communes $(-0.0959)$ and in urban-rural communes (0.0986). In urban-rural communes, increasing expenditure on salaries of public officers has a positive impact on the level of entrepreneurship.

Taking into consideration that the variable called expenditure of communes on administration/total population has a very small importance, it should be noted that in the case of urban communes $(0.0186)$ and rural communes (0.0018) the ratios take positive signs but in the case of urbanrural communes a negative sign $(-0.0083)$. This can testify that in the urbanrural communes in the structure of local budgets, the authorities should not increase this type of expenditure, if the self-government's priority is to increase the entrepreneurship level.

The variable called non-wage expenditure of communes/total population had a small impact on entrepreneurship. In the case of urban and urban-rural communes, the ratios were positive, at respectively (0.0186) and (0.0098), and when it comes to the value of this ratio in rural communes, it was equal to $(-0.0036)$.

Based on the conducted research, the authors can state that there is a relationship between the size of local government administration and entrepreneurship. Broadly speaking, the increased size of the administration negatively affects entrepreneurship. The biggest impact on the number of new enterprises was observed in urban communes, where the variable called expenditure on salaries of public officers/total population relatively strongly influenced entrepreneurship. The correlation had a negative sign, suggesting that the increase in expenditure on salaries of public officers has a negative impact on the level of entrepreneurship. In the case of other variables presenting size of administration and remaining types of communes, the relationships were not as strong as in the case of the variable called expenditure on salaries of public officers/total population.

The presented research findings are an emanation of the dependence resulting from budgetary practice. Higher spending on salaries results in a higher value of current expenditure, and thus the higher their share 
in total budget expenditure. The more the commune spent on current expenditure, the lower the level of capital expenditure (including current expenditure). The effect of higher current expenditure is lower than the level of capital expenditure, which could contribute to creating conditions for the development of entrepreneurship. In addition, the higher the level of current expenditure, the lower is the rate of free cash in the communes, i.e. capital that allows entities to engage in activities other than the current tasks (related to the implementation of tasks assigned to the commune in the statutory sense), i.e. investment activities.

There is one more issue that should be emphasized and was suggested by the results of the conducted calculations. Higher spending on wages can mean not only higher salaries for a smaller number of public officers, but also a larger number of officers themselves - and this may cause difficulties in determining the "owner" of individual tasks at the office, i.e. an indication of the structure of the office - official/officials or even investigators or departments that are responsible for policy supporting entrepreneurship. This is the cause of obfuscation in competence, which can be translated into both limited innovativeness in activities aimed at entrepreneurship's stimulation and their lower effectiveness. Lack of clear assignment of such tasks to a particular department (officer/group of officers) may cause two situations. Firstly, the task can be allocated to all officers that deal with any tasks from the "area of entrepreneurship" and the officials will be trying to solve the problem individually (some actions may be inconsistent or incompatible). Secondly, the task will not be clearly allocated to a particular investigator (department/official or group of officials), which causes a situation of their marginalization or displacement of priorities of its implementation.

Finally, taking into consideration the above arrangements it has to be stated that a large number of public officers corresponds with a complex structure of the office, which could result in, among other things, difficulties in the flow of information on the realized tasks, or the nature and forms of involvement in efforts to stimulate local economic development - between the public officers, investigators or even departments. This in turn may result in a lack of coordination in the support of entrepreneurship within the structures of the office and in effect lowers the effectiveness of support that is based on separate activities (often independent). This conclusion comes from practical experience. The specificity of Polish local government is development policy that is not very coordinated internally (and thus inconsistent). Efforts to create conditions to support entrepreneurship are often initiated in the structure of the offices in an independent way by various investigators and departments. As a result, the achieved effects are much smaller than the potential. A common problem is not only individualism of 
actions, but the lack of their internal coherence combined with coordination that is concentrated on one center located in the decision-making structure of the office. An effect of this condition are the relatively rare decisions that are taken by communes and aimed to create comprehensive programs of entrepreneurship development, which should organize the policy of support in order, considering both instruments and those responsible for their implementation and monitoring investigators and departments. The showcase of such a communal "model" of policy supporting entrepreneurship are singular, activities aimed at entrepreneurship, problems in the flow of information within the structures of office, and unclear communication policy along the lines of: office - entrepreneur.

All of the above factors combined together make up the negative connotation of the relationship between the size of public administration at local government level and the local entrepreneurship. This article shows the multidimensionality and complexity of the examined phenomenon. This fact leads the authors to believe that the actions taken and individually implemented solutions to improve entrepreneurship will bring similar halfhearted results. In addition to the proven fact of negative dependency along the lines of: size of local government - entrepreneurship, it is also necessary to realize the true scale and diversity of the factors that make up the result of this relationship. Only if governments understand that, besides the obvious (shown in the results of this study) cause of a weaker development of entrepreneurship, which is the size of local government, has a much broader base, will it be possible to initiate effective action to stimulate new business initiatives. Reduction (and in the most optimistic minimum scenario - not growth) of the size of the administrative structure is thus a necessary condition, but not sufficient for building the foundations for a fully effective entrepreneurship stimulation.

\section{Acknowledgements}

The article was prepared based on the results of a project that was financed from the funds of the National Science Centre given by decision number DEC2013/11/B/HS4/01022.

\section{References}

Acs, Z. J. \& Szerb, L. (2007). Entrepreneurship, economic growth and public policy. Small Business Economics, 28(2-3), 109-122.

Aidis, R., Estrin, S. \& Mickiewicz, T. M. (2012). Size matters: Entrepreneurial entry and government. Small Business Economics, 39(1), 119-139.

Anderson, J. E. (2011). Public Finance. Boston: Wadsworth, Cengage Learning. 
Bania M. \& Dahlke P. (2014). Samorząd terytorialny jako potencjalne źródło wsparcia sektora MŚP na przykładzie Wielkopolski. In D. J. Mierzejewski and J. Polcyn (Eds.), Gospodarka w warunkach integracji europejskiej. Economy Under European Integration (pp. 69-85). Piła: Wydawnictwo Państwowej Wyższej Szkoły Zawodowej im. Stanisława Staszica w Pile.

Baqir, R. (1999). Districts, spillovers and government overspending, Policy Research Working Paper 2192, World Bank, Washington, DC.

Schmidt, S. W., Shelley, M. C., Bardes, B. A. \& Ford, L. E. (2013). American Government and Politics Today, 2013-2014 Edition. Boston: Wadsworth, Cengage Learning.

Bjørnskov, C. \& Foss, N. (2008). Economic freedom and entrepreneurial activity: Some cross-country evidence. Public Choice, Public Choice, 134(3-4), 307-328.

Boex, J. (2011). Exploring the Measurement and Effectiveness of the Local Public Sector: Toward a classification of local public sector finances and a comparison of devolved and deconcentrated finances. IDG Working Paper No. 2011-05, Urban Institute Center on International Development and Governance, Washington, DC.

Boex, J. (2012). Providing basic public services at the door step of the people? Estimating the size of the local public sector in Bangladesh. IDG Policy Brief June 2012, Urban Institute Center on International Development and Governance, Washington, DC.

Casero, J. C. D., Aunión, Á. M. D., Escobedo, M. D. L. C. S. \& Mogollón, R. H. (2015). Size of government and entrepreneurship. Analysis of three groups of countries with different economic development. FAEDPYME International Review-FIR, 4(6), 45-57.

Djankov, S., La Porta, R., Lopez-de-Silanes, F. \& Shleifer, A. (2002). The regulation of entry. The Quarterly Journal of Economics, 117(1), 1-37.

Dollery, B. \& Robotti, L. (2008). Alternative models of local government. In B. Dollery and L. Robotti (Eds.), The Theory and Practice of Local Government Reform (pp. 27-52). Cheltenham: Edward Elgar Publishing.

Dropek, K. (2014). Działania samorządu terytorialnego wspierające przedsiębiorczość w gminach województwa wielkopolskiego. Studia Oeconomica Posnaniensia, 2(2), 263.

Dyrda G. (2014). Działania samorządu terytorialnego wspierające przedsiębiorczość - determinantę rozwoju lokalnego, wspierania lokalnej przedsiębiorczości (na przykładzie wybranych gmin podkarpacia). Gospodarka i Finanse, 4, 89-99.

El-Namaki, S.S. (1988). Encouraging entrepreneurship in developing countries. Long Range Planning 21(4), 98-106.

Fuentelsaz, L., González, C., Maícas, J. P. \& Montero, J. (2015). How different formal institutions affect opportunity and necessity entrepreneurship. BRQ Business Research Quarterly, 18(4), 246-258.

Garand J.C., Ulrich J. \& Ping, Xu. (2013). Fiscal policy in the American States. In D. Haider-Markels (Ed.), The Oxford Handbook of State and Local 
Government Politics, a volume of Oxford Handbooks of American Politics (pp. 611-643). New York: Oxford University Press.

Garrett, T. A. \& Rhine, R. M. (2006). On the size and growth of government. Review-Federal Reserve Bank of Saint Louis, 88(1), 13.

Gnyawali, D. R. \& Fogel, D. S. (1994). Environments for entrepreneurship development: Key dimensions and research implications. Entrepreneurship Theory and Practice, 18, 43-43.

Goodman, J. P., Meany, J. W. \& Pate, L. E. (1992). The government as entrepreneur: Industrial development and the creation of new ventures. In D. Sexton and J. Kasarda (Eds.), The State of the Art of Entrepreneurship (pp. 301-340). Boston: PWS-Kent Publishing Co.

Grycuk, A. \& Russel, P. (2014). Zaangażowanie jednostek samorządu terytorialnego $w$ Polsce $w$ tworzenie instytucji wspierających przedsiębiorczość. Studia BAS, (1), 65-83.

Heckelman, J. C. (2000). Economic freedom and economic growth: A shortrun causal investigation. Journal of Applied Economics, 3(1), 71-91.

Heller, P. S. \& Tait, A. A. (1983). Government employment and pay: Some international comparisons, Occasional Paper No. 24, International Monetary Fund, Washington, DC.

Chu, K. Y. \& Hemming, R. (Eds.). (1991). Public Expenditure Handbook: A Guide to Public Policy Issues in Developing Countries, Washington, DC: International Monetary Fund.

Henrekson, M. (2005). Entrepreneurship: a weak link in the welfare state?. Industrial and Corporate Change, 14(3), 437-467.

Higgins, M. J., Levy, D. \& Young, A. T. (2006). Growth and convergence across the United States: Evidence from county-level data. The Review of Economics and Statistics, 88(4), 671-681.

Hodler, R. (2009). Industrial policy in an imperfect world. Journal of Development Economics, 90(1), 85-93.

Islam, A. (2015). Entrepreneurship and the allocation of government spending under imperfect markets. World Development, 70, 108-121.

Ivanov, S., Tchavdarova, G., Savov, E. \& Stanev, H. (2002). Does larger mean more effective? Size and the function of governments in Bulgaria. In P. Swianiewicz (Ed.), Consolidation or Fragmentation (pp. 167-217). Budapest: Local Government and Public Service Initiative.

Kalseth, J. \& Ratts $\varnothing$, J. (1995). Spending and overspending in local government administration: A minimum requirement approach applied to Norway. European Journal of Political Economy, 11(2), 239-251.

Klapper, L., Laeven, L. \& Rajan, R. (2006). Entry regulation as a barrier to entrepreneurship. Journal of Financial Economics, 82(3), 591-629.

Koellinger, P. \& Minniti, M. (2009). Unemployment benefits crowd out nascent entrepreneurial activity. Economics Letters, 103(2), 96-98.

Korolewska, M. (2014). Polityka podatkowa gmin i miast na prawach powiatu w zakresie podatku od nieruchomości a wspieranie przedsiębiorczości przez samorząd terytorialny. Studia BAS, (1), 85-108. 
Labonte, M. (2010). Size and Role of Government: Economic Issues. Washington DC: DIANE Publishing.

Larroulet, C. \& Kouyoumdjian, J. P. (2009). Entrepreneurship and growth: A Latin American paradox?. The Independent Review, 14(1), 81-100.

Mackenzie, G.A. (1991). Public sector employment. In K.Y. Chu \& R. Hemming (Eds.), Public Expenditure Handbook: A Guide to Public Policy Issues in Developing Countries (pp. 41-46). Washington, DC: International Monetary Fund.

Minniti, M. (2008). The role of government policy on entrepreneurial activity: Productive, unproductive, or destructive?. Entrepreneurship Theory and Practice, 32(5), 779-790.

Motoyama, Y. \& Wiens, J. (2015). Guidelines for Local and State Governments to Promote Entrepreneurship. Kansas City: Ewing Marion Kauffman Foundation.

Nica, M. (2013). Spending allocation and entrepreneurship. Journal of International Entrepreneurship, 11(4), 351-369.

Nyström, K. (2008). The institutions of economic freedom and entrepreneurship: Evidence from panel data. Public Choice, 136(3-4), 269-282.

Parker, S. C. (2004). The Economics of Self-Employment and Entrepreneurship. Cambridge: Cambridge University Press.

Parker, S. C. (2007). Law and the economics of entrepreneurship. Comparative Labor Law and Policy Journal, 28(4), 695-716.

Pevcin, P. (2012). Local government in Slovenia: Structure, size, and expenditure. Croatian and Comparative Public Administration, 12(3), 705-724.

Phillips, K. L. \& Chen, B. (2007). A panel data sensitivity analysis of regional growth in China. In L. Shuanglin and Z. Xiaodong (Eds.), Private Enterprises and China's Economic Development (pp. 126-141). London, New York: Routledge.

Rapacz A. \& Jaremen D. E. (2014). Rola władz lokalnych powiatu jeleniogórskiego w pobudzaniu przedsiębiorczości w turystyce. Folia Turistica, (32), 215-241.

Salvino, R. (2007). Home Rule Effects on State and Local Government Size. Urban and Regional Analysis Group Working Paper No 701, Georgia State University, Georgia.

Sellers, J. M., Barnes, J., Hoffmann-Martinot, V. \& Shipper, A. (2003). Between national state and local society: Infrastructures of local governance in developed democracies. In University of South California, Paper presented at Urban Affairs Association Annual Meeting, Cleveland, $\mathrm{OH}$.

Shane, S. (2009). Why encouraging more people to become entrepreneurs is bad public policy. Small Business Economics, 33(2), 141-149.

Skica, T., Bem, A. \& Żygadlo, K. (2013). The role of local government in the process of entrepreneurship development. e-Finanse, 9(4), 1-24. 
Skica, T. \& Bem, A. (2014). Rola samorządu terytorialnego w procesach stymulowania przedsiębiorczości. Studia Regionalne i Lokalne, 1(55), 7992.

Smallbone, D. (2007). Institutions, governance and development of entrepreneurship in Central and Eastern Europe. In S. Giguere (Ed.), Local innovations for growth in Central and Eastern Europe (pp. 165183). Paris: OECD.

Smallbone, D. \& Welter, F. (2001). The role of government in SME development in transition economies. International Small Business Journal, 19(4), 6377.

Valdez, M. E. \& Richardson, J. (2013). Institutional determinants of macrolevel entrepreneurship. Entrepreneurship Theory and Practice, 37(5), 1149-1175.

Van Stel, A., Storey, D. J. \& Thurik, A. R. (2007). The effect of business regulations on nascent and young business entrepreneurship. Small Business Economics, 28(2-3), 171-186.

Vesper, K. H. (1983). Entrepreneurship and National Policy. Chicago: Walter E. Heller International Corporation Institute for Small Business.

Walenia, A. (2014). Rola instytucji w procesie wspierania lokalnej przedsiębiorczości (na przykładzie wybranych gmin podkarpacia). Gospodarka i Finanse, 4, 61-73.

Weiher, G. R. \& Lorence, J. (1991). Growth in state government employment: A time series analysis. Political Research Quarterly, 44(2), 373-388.

Westhead, P. (1990). A typology of new manufacturing firm founders in Wales: Performance measures and public policy implications. Journal of Business Venturing, 5(2), 103-122.

Westlund, H. \& Bolton, R. (2003). Local social capital and entrepreneurship. Small Business Economics, 21(2), 77-113.

\begin{abstract}
Polish)
Niniejszy artykuł przyjmuje za cel zbadanie zależności pomiędzy rozmiarem administracji publicznej szczebla lokalnego, a poziomem przedsiębiorczości w poddanych badaniu jednostkach samorzadu gminnego w Polsce. Opracowanie stanowi próbę odpowiedzi na pytanie, czy rozmiar administracji samorzqdowej ma charakter stymulanty, czy destymulanty w procesie zakładania działalności gospodarczej. Innymi słowy, czy rozmiar administracji publicznej na szczeblu lokalnym (gminnym), wpływa pozytywnie, czy negatywnie na tworzenie nowych podmiotów gospodarczych. Podjęte $w$ artykule zagadnienie jest istotne co najmniej z kilku powodów. Po pierwsze, obecny dorobek naukowy nie obfituje w publikacje łączqce przedsiębiorczość z rozmiarami administracji samorzqdowej. Po drugie, zagadnienie determinant przedsiębiorczości, stanowi wciq̨ż aktualny i nie w pełni zbadany (wyjaśniony), aspekt rozwoju lokalnych gospodarek. Finalnie, po trzecie, autorzy w ramach niniejszego tekstu proponujq autorskie podejście do kwantyfikacji rozmiaru administracji samorzqdowej, modyfikujqc stosowane powszechnie miary lokalnej administracji publicznej. Majqc na uwadze przytoczonq argumentację, niniejszy artykuł nie tylko wpisuje się w wyja-
\end{abstract}


śnianie „zjawiska” przedsiębiorczości i jego determinant, ale również przyczynia się do budowania wiedzy o zależnościach pomiędzy rozmiarem samorzqdu lokalnego a poziomem przedsiębiorczości. Artykuł wypełnia tym samym lukę w aktualnym podejściu do badań nad zwiqzkiem na linii: przedsiębiorczość - rozmiar administracji samorzadowej. Rozszerza on zasób wiedzy o analizowanych zależnościach i reorientuje dotychczasowe podejścia do badań, z efektów działania władz publicznych służqcych wspieraniu inicjatyw gospodarczych, na rozmiar administracji samorzqdowej jako czynnik wpływajqcy na poziom przedsiębiorczości.

Słowa kluczowe: samorzqd terytorialny; lokalna administracja publiczna; administracja samorzqdowa; rozmiar samorzqdu lokalnego; przedsiębiorczość; nowozakładane podmioty gospodarcze.

\section{Biographical notes}

Rusłan Harasym. Author or co-author of publications devoted to macroeconomics and international economic relations. His fields of interest include foreign direct investments (FDI). He is Associated professionally with the University of Information Technology and Management (UITM) in Rzeszow and is an Assistant in the Department of Economics at UITM.

Jacek Rodzinka. Doctor of economic sciences. His fields of interest include the topic of customer loyalty in various branches, in particular in the field of insurance. Scientifically, he is involved in the modelling and measurement of customer loyalty. An author or co-author of over forty publications and many reports, expertise's and development strategies and a trainer and consultant working with both academic centers as well as businesses. Since 1999 he has been on the staff at the University of Information Technology and Management (UITM) in Rzeszow. He is currently in the positions of Director of the Center for Socio-Economic Clustering Research and Analysis, and Director for Commercial Development in the Institute for Financial Research and Analyses in Rzeszow.

Tomasz Skica. Doctor of economic sciences. He is Director for Research and Science in the Institute for Financial Research and Analyses in Rzeszow and since 2002, has been associated professionally with the University of Information Technology and Management (UITM) in Rzeszow. An expert in public finance (in particular the financing of local public administration) he also conducts training and consultations in the field of local government finance. The author and co-author of financial strategies and development programs, focused on the local government level, as well as expertise on finance for local governments. He is also the author of several academic 
articles, books, monograph sections, analytical works and reports, as well as remedial strategies and programs in the field of public finance, with an emphasis on local public administration entities. 
